\title{
OECD National Contact Points as Sites of Effective Remedy: New Expressions of the Role and Rule of Law within Market Globalization?
}

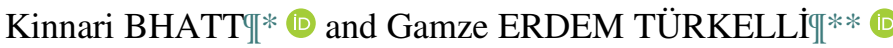

\begin{abstract}
National Contact Points (NCPs), which support the OECD Guidelines for Multinational Enterprises, are often invoked as a reliable state-based mechanism for holding transnational corporations accountable for business-related human rights abuses. The objective of this article is to scrutinize the ability of NCPs to offer effective remedy through the lens of an often-quoted success story (the case of the post-colonial brewery Bralima-Heineken at the Dutch NCP) and through a few existing studies that examine factors that curtail or enhance the possibility of NCP mechanisms to deliver effective remedy. Based on these findings, we suggest specific 'actions for effectiveness' in the form of recommendations for improving NCPs as a tool to deliver effective remedy. Zooming out, we extend some general observations on how our findings illustrate that NCPs are expressions of a larger systemic problem surrounding the role of law within market globalization and the impact of economic liberalization on the making of norms, changing legal authority and basic fairness under conditions of stark power imbalance. Supporting this approach are historical factors which make the OECD Guidelines and NCPs ripe for such conceptualization.
\end{abstract}

Keywords: Bralima-Heineken, NCPs, political economy, remedy, rule of law

\section{INTRODUCTION}

National Contact Points (NCPs), which support the Organization for Economic Cooperation and Development $(\mathrm{OECD})^{1}$ Guidelines for Multinational Enterprises

II Conflicts of interest: The authors declare none.

* Kinnari Bhatt is Senior Legal Advisor at Norinchukin Bank Europe and expert with the Independent Redress Mechanism of the Green Climate Fund. Affiliation: Erasmus Universiteit Rotterdam, the Netherlands.

** Gamze Erdem Türkelli is a Post-Doctoral Fellow of the Research Foundation (FWO) Flanders No: 12Q1719N at the University of Antwerp Law and Development Research Group (Antwerp, Belgium).

1 The OECD is a unique forum where industrialized governments and emerging economies work together to address the economic, social and environmental challenges of globalization. 
(OECD Guidelines), are often invoked as a crucial non-judicial mechanism for holding multinational enterprises (MNEs) accountable for business-related human rights abuses. Established in 1984, NCPs acquired a remedial function under the OECD Guidelines only from $2000 .^{2}$ NCPs celebrated their 20th anniversary as an access to remedy mechanism in 2020 but their effectiveness continues to be questioned. ${ }^{3}$ In this context, the objective of this article is to subject NCPs to empirically grounded scrutiny on their ability to offer effective remedy. We analyse this question through the lens of an often-quoted success story (the case of the post-colonial brewery Bralima-Heineken at the Dutch NCP) and through a few existing studies that examine various factors that curtail or enhance the possibility of NCP mechanisms to deliver effective remedy.

Marking this anniversary, the OECD released a report, '20 years and the road ahead'. ${ }^{4}$ Taking stock of the challenges faced by NCPs in delivering their role, the report recognizes the significant contributions they have made in addressing the negative impacts of MNE activity worldwide and looks ahead at how weaknesses within the NCP system could be practically addressed. This analysis is conducted through 20 notable NCP cases. Each of these emblematic cases illustrates the wide and complex variety of facts and contexts handled by NCPs. Directly relevant to this article is the choice of the Bralima-Heineken case as one of those 20 key cases demonstrating how NCPs have made a positive difference. In Bralima, those contributions manifested in the form of facilitating lengthy mediation through embassies, culminating in concrete financial compensation. Reading across these emblematic cases demonstrates that no two cases brought before NCPs are the same or inherently easier than others. Instead, these cases show the uniqueness of each in terms of the issues dealt with within a highly specific context, history, geography and range of actors.

Adopted in 1976, the OECD Guidelines are unique as they require OECD member countries and those non-OECD countries that adhere to the OECD Guidelines, to secure the implementation of the same on the part of MNEs operating in or from adhering countries, wherever those companies may be operating. In this respect the OECD Guidelines constitute the 'only [comprehensive] corporate responsibility instrument formally adopted by states' ${ }^{5}$ that operates in a global context. As recommendations addressed by governments to MNEs operating in or from adhering countries, the OECD Guidelines provide non-binding standards for responsible business conduct and are consistent with applicable laws and internationally recognized standards such as the United Nations Guiding Principles on Business and Human Rights (UNGPs). In 2011, they were

\footnotetext{
2 OECD, 'Key Findings: Implementing the OECD Guidelines for Multinational Enterprises: The National Contact Points from 2000 to 2015' (2016), https://mneguidelines.oecd.org/15-Years-of-the-National-Contact-PointsHighlights.pdf (accessed 13 May 2021).

3 OECD Watch, 'The State of Remedy under the OECD Guidelines Understanding NCP Cases Concluded in 2018 Through the Lens of Remedy', OECD Watch Briefing Paper (8 June 2019), https://www.oecdwatch.org/wp-content/ uploads/sites/8/2019/06/State-of-Remedy-2018-2019-06-08.pdf (accessed 19 June 2020).

4 OECD, 'National Contact Points for Responsible Business Conduct, Providing Access to Remedy: 20 Years and the Road Ahead', http://mneguidelines.oecd.org/ncps/ncps-at-20/ (accessed 31 January 2021).

5 Jernej Letnar Černic, 'Corporate Responsibility Human Rights: A Critical Analysis of the OECD Guidelines for Multinational enterprises' (2008) 4:1 Hanse Law Review 71. The International Labour Organisation's Tripartite Declaration of Principles concerning Multinational Enterprises and Social Policy is also adopted by states, businesses and trade unions but only covers social and labour policies.
} 
updated to reflect the content espoused in the UNGPs, in particular the responsibility of companies to undertake human rights due diligence to identify, prevent and mitigate adverse impacts of their business ventures. The aim of adhering governments is to encourage the positive contributions that MNEs can make to economic, environmental and social progress and to minimize their adverse impacts. The governments adopting the OECD Guidelines must set up NCPs which are, in turn, required to operate in a functionally equivalent manner regardless of how they are individually structured. ${ }^{6}$

Given that the NCP mechanism provides one of the few avenues for individuals and communities to attempt to correct some of the structural barriers for remedy created by a legal international economic order pre-occupied with states and the pursuit of economic profitability, a conceptual analysis of NCPs would allow us to revisit and test some basic questions about the role of law in the global political economy through a fresh empirical lens. This discussion raises some general questions: What do NCPs say about contemporary norm and subject creation? What do NCPs tell us about new forms of legal authority?

Taken further, NCPs provide us with new entry points through which we can make useful observations about what happens to effective legal redress and accountability within the current political economy of power and inequality. ${ }^{7}$ The inadequacy of the neoliberal response to correcting the negative impacts of transnational power relationships within today's hyper-pluralized economic order of trade and market liberalization exposes a systemic problem surrounding the role of law within market globalization. NCPs constitute one expression or symptom of this problem.

Having provided a broad overview, section II sets out the theoretical background informing how NCPs are situated within a larger framework surrounding the role of law within market globalization and the impact of economic liberalization on core rule of law concerns such as norm creation, changing legal authority and basic fairness under conditions of stark power imbalance. Supporting this approach are historical factors which make the OECD Guidelines and NCPs ripe for such conceptual debate. Yet, despite these clear systemic shortcomings, it is important to recognize that NCPs continue to serve a function for rights-holders and those currently seeking remedies. Therefore, section III sets out the empirical and conceptual approach to the research question of whether NCPs do and can provide effective remedy by first defining what is understood by effective remedy.

Section IV then dives deeper into the question by interrogating it through findings from a well-attended expert workshop jointly organized by the INFAR (Integrating Normative and Functional Approaches to the Rule of Law) project at Erasmus School of Law and the Asser Institute in the Netherlands in 2019. ${ }^{8}$ The event sought to examine the effectiveness of NCPs to offer access to remedy and placed specific focus on the Bralima-Heineken

\footnotetext{
6 All NCPs must operate in accordance with a set of criteria which include visibility, accessibility, transparency and accountability. OECD, Procedural Guidance, Commentary on the Procedural Guidelines for NCPs (Paris: OECD, 2011), section 1 , introductory paragraph.

7 Michael Wilkinson and Hjalte Lokdam, 'Law and Political Economy', LSE Law, Society and Economy Working Papers 7/2018, http://eprints.lse.ac.uk/87544/1/Wilkinson_Law\%20Political\%20Economy_Author.pdf (accessed 23 October 2020).

8 TMC Asser Institute, 'Workshop: How Effective are the OECD National Contact Points? Lessons from the Bralima Case', Asser Institute (3 April 2019), www.asser.nl/education-events/events/?id=3068 (accessed 19 June 2020).
} 
case as it is frequently portrayed as a NCP success story. The section then situates the Bralima case within the existing literature on the OECD Guidelines and NCPs. This contextualization paints a mixed picture of NCP performance with some successful mediated agreements, but also many instances of weak performance. Based on this empirical analysis, we formulate specific recommendations for improving NCPs as a tool to deliver effective remedy. Section V concludes.

\section{NCPs Within Today's Global Political Economy}

Since establishment of the remedial function of NCPs in 2000, the relationship between the OECD Guidelines and NCPs has evolved from a promotional and enquiry centred role towards one which sees NCPs providing a practical forum for encouraging dialogue, problem solving and adjudicating disputes on issues relating to the OECD Guidelines. Given the breadth of areas covered by the OECD Guidelines including human rights, labour, environment, consumer interests, corruption, competition and taxation, NCPs are capable of hearing a diverse range of issues. Nonetheless, most frequently heard are disputes over human rights, due diligence and labour relations. ${ }^{9}$

NCP cases are called 'specific instances'. The specific instance process is governed by a Procedural Guidance attached to the OECD Guidelines. An individual, organization or community with an interest in the matter may report issues related to the Guidelines implementation. When NCPs receive a complaint, they follow a simple three-step process: initial assessment, good offices and conclusion. NCPs do not, however, have the authority to deliver legal remedy and enforceable decisions, but rather act as a forum for discussion aimed at resolving issues that arise during the implementation of the OECD Guidelines.

This is a key functional point that is sometimes overlooked or misinterpreted in attempts to link NCPs to the third pillar of the UNGPs on access to remedy. The OECD Guidelines and the Procedural Guidance do not present or promote NCPs as mechanisms for effective remedy. That misinterpretation is at least partly because NCPs are mentioned in the UNGPs as a state-based grievance mechanism for affected people to seek remedy through an intermediary on their behalf. ${ }^{10}$

Subsequently, a gap opens between expectation and functional reality in the eyes of those seeking remedy. So, claimants may come to NCP good offices to facilitate access to remedy and justice, ${ }^{11}$ an expectation that will misalign with the functional realities of NCPs. In challenging and even violent domestic contexts, as illustrated in the Bralima case, this can cause on-the-ground conflicts between the rules and the realities of those seeking justice and remedy. Yet, NCPs might be the only remedial tool available for many individuals and communities, particularly given the relative absence of other judicial and

9 OECD, '20 Years and the Road Ahead', note 4.

10 The commentary to Principle 25 of the UNGPs lists NCPs alongside other mechanisms such as courts and labour tribunals. UN Human Rights Council, 'Guiding Principles on Business and Human Rights: Implementing the United Nations "Protect, Respect and Remedy” Framework', A/HRC/17/31 (21 March 2011), Commentary to Principle 25.

11 Reference is made to a participant at the 2019 workshop. 
non-judicial mechanisms to address business wrongdoings. At that juncture, the extent to which an NCP can serve as an effective point of departure for individuals seeking corporate accountability becomes highly pertinent for the individual and also for the legitimacy of the NCP system as a whole.

Critical legal scholars ${ }^{12}$ have developed a thesis on the connectivity of legal institutions and power in a variety of state and non-state contexts, including how international law has its origins in a colonial encounter. Within this context, international law was deployed as an instrumental tool to displace and subjugate native cultures, privately accumulate (ab)original titles to land and resources and interfere with the freedom and choices of others. ${ }^{13}$ Koskenniemi has argued that the principal legacy of early political relations that evolved into international law was the development of a vocabulary of private rights (of dominium). This enabled the universal ordering of international relations by recourse to contract, private property and commercial exchange, to create an 'informal empire' over the rest of the world which continues through the exercise of private power and laws of contract. ${ }^{14}$

Beyond such larger theorizing, there has traditionally been limited discussion about the detailed intricacies and mechanisms around which legal concepts and structures facilitate capitalism today. Critical international economic law (IEL) and law and development scholarship is thankfully connecting previously unconnected dots between international law's historical violence and specific modern practices of economic domination within private legal modalities. Numerous fields are ready for such deconstruction including the structures of investment treaty law and arbitration, ${ }^{15}$ the virtual impossibility of holding international financial institutions to account under international law, ${ }^{16}$ and law in transnational development projects. ${ }^{17}$ Similarly, applying a critical conceptual approach to NCPs presents an opportunity to add new perspective to a perennial problem: what is happening to the rule of law and constitutionalism under the conditions of market globalization and multi-level governance and authority, ${ }^{18}$ of which the OECD Guidelines are one example? Specifically, this new perspective relates to a two-pronged exercise. First, it seeks to structurally and historically

12 Roberto M Unger, 'The Critical Legal Studies Movement' (1983) 96 Harvard Law Review 561; Owen M Fiss, 'The Death of the Law?' (1986) 72:1 Cornell Law Review 1.

13 Anthony Anghie, Imperialism, Sovereignty, and the Making of International Law (Cambridge: Cambridge University Press, 2007).

14 Martti Koskenniemi, 'Empire and International Law: The Real Spanish Contribution' (2011) 61:1 University of Toronto Law Journal 1.

15 David Schneiderman, 'The Coloniality of Investment Law' (May 2019), http://ssrn.com/abstract=3392034 (accessed 19 June 2020).

16 John Linarelli, Margot E Salomon and Muthucumaraswamy Sornarajah, The Misery of International Law: Confrontations with Injustice in the Global Economy (Oxford: Oxford University Press 2018).

17 Lorenzo Cotula, 'Law and Political Economy of Commodity Rushes: Reflections on "Land Grabbing" in the Global South', LPE Blog (5 September 2019), https://lpeproject.org/blog/law-and-political-economy-of-commodityrushes-reflections-on-land-grabbing-in-the-global-south/ (accessed 23 October 2020). Bhatt also illuminates the private laws of contract used by private actors to structure and implement development projects and the impact of those legal structures for displacing the rights of affected communities. Kinnari Bhatt, Concessionaires, Financiers and Communities: Implementing Indigenous Peoples' Rights to Land in Transnational Development Projects (Cambridge: Cambridge University Press, 2020).

18 Kinnari Bhatt, Jennifer Lander and Sanne Taekema, Reviews Symposium: 'The Rule of Law in Transnational Development Projects - Private Actors and Public Chokeholds' (2021) 17:1 International Journal of Law in Context 91. 
contextualize the OECD Guidelines and NCPs within IEL as a field. Second, it is concerned with seeing how the functions of NCPs might impact upon solid statecentric rule of law principles: the production of legal authority, access to justice, accountability and legal predictability, which are all affected by accelerated globalization.

\section{A. Structural and Historical Contextualization}

Having been formally adopted by states, the OECD Guidelines remain within international law's formal state-centric architecture. IEL clearly relates to issues of a transnational character that span public and private actors through public international law of trade to private international law of trade to certain aspects of international commercial law and the law of international finance and investment. ${ }^{19}$ Nonetheless, given that even the most orthodox view of IEL covers the economic relations between states, it is unusual that the OECD Guidelines and NCPs, many of which are housed within government departments and thus enjoy a direct connection to state apparatus and seek to regulate economic activities through the intervention of states, have thus far not been situated within this field.

The history of the OECD Guidelines illustrates that they were borne on the heels of the New International Economic Order (NIEO), ${ }^{20}$ which was the outcome of the concerns over the role of law in the creation of an unequal international economic regime that contributed to power imbalances and 'adverse effects' upon the social, economic and political systems of developing countries. ${ }^{21}$ At the core of the NIEO's agenda was a series of inter-related proposals for reforms to the structure of the global economy. One of those reforms was to regulate the behaviour of MNEs. The OECD Guidelines would play a part in 'taming' MNE influence over developing country economies. ${ }^{22}$

The OECD Guidelines were, however, negotiated and implemented by industrialized nations, essentially for industrialized nations giving them a protectionist characteristic. Subsequently, they were entirely directed at the supply side of investment, the rule makers rather than the rule takers, or the global 'winners' over the global 'losers' in non-OECD countries. As of the time of writing, all thirty-seven industrialized or emerging economy OECD countries and only thirteen non-OECD countries $^{23}$ have signed up to the Guidelines and are thus compelled to establish NCPs. This demonstrates how free market economy focused OECD countries (or those on that trajectory) continue to set the rules for NCP functions and practices. These rules are then outsourced to activities and decisions of MNEs in developing countries and will subsequently influence how individuals and communities will experience remedy in practice. Of course, today's

\footnotetext{
19 Roger Cotterell, 'Transnational Networks of Community and International Economic Law' in Amanda PerryKessaris (ed), Socio-Legal Approaches to International Economic Law (Abingdon: Routledge, 2013) 133.

20 Nils Gilman, 'The New International Economic Order: A Reintroduction' (2015) 6:1 Humanity Journal 1.

21 Susan A Aaronson, 'Global Corporate Social Responsibility Pressures and the Failure to Develop Universal Rules to Govern Investors and States' (2002) 3:3 The Journal of World Investment and Trade 487.

22 Gamze Erdem Türkelli, Children's Rights and Business: Governing Obligations and Responsibility (Cambridge: Cambridge University Press, 2020) 50.

23 OECD, 'OECD Declaration and Decisions on International Investment and Multinational Enterprises', https:// mneguidelines.oecd.org/oecddeclarationanddecisions.htm (accessed 23 October 2020).
} 
globalization rapidly overtook efforts to achieve the NIEO and we can see some practical implications of this in the fragmented and obscure functions and practices of NCPs discussed in the previous sections. The institutional foundations of the Guidelines are symptomatic of an international economic order rooted in multinational power, Global North-South power imbalances, democratic interference and social and political unrest, that also contributes to understanding the operational effectiveness of NCPs today.

\section{B. NCPs and the Rule of Law}

The rule of law serves as a central ideal of legal systems, both national and international, the value of which is given concrete shape in response to the context in which it is at work. We understand the rule of law as a living and relative principle rather than an absolute and static one. In theory at least, the rule of law principles do (and should) apply to private actors. ${ }^{24}$ As a UN General Assembly resolution points out, an environment that upholds the rule of law is or should be the shared interests of businesses, States and civil society. ${ }^{25}$ Krygier's focus on the rule of law sees it as far more than a procedural (anatomical) checklist for measuring the good (or bad) health of a legal system. For Krygier, the rule of law takes on a socio-contextual feel because it concerns the activities of all persons and institutions capable of exercising significant power in society ${ }^{26}$ and consequently, can be used and misused to serve specific purpose. Krygier's rule of law is about how power works in society rather than abstract definitional debates.

Applying this approach, it is problematic that in the field of IEL, the rule of law has been used by states, businesses, financial institutions and banks as a substantive instrument to achieve highly specific ends over all others: economic growth and particularly private sector development to achieve growth and the furtherance of capital. ${ }^{27}$ As May notes, 'the rule of law has become a key element in the (re)production of capitalist market relations'. ${ }^{28}$ This highly particular version of the rule of law focuses on an economically liberal and thin subset of individual rights such as rights of private property, sanctity of contract, high contractarian approaches of laissezfaire and mature creditors rights as key requirements. ${ }^{29} \mathrm{In}$ fact, it has been argued that IEL more generally has - through a global legal architecture of trade, investment and financeprioritized the sanctity of agreements and economic freedom over all other values. ${ }^{30} \mathrm{In}$ this context, the rule of law takes on a specific meaning: becoming denationalized and

\footnotetext{
24 Robert McCorquodale, 'Defining the International Rule of Law: Defying Gravity?' (2016) 65:2 International and Comparative Law Quarterly 277.

25 Human Rights Council, 'Business and Human Rights: Improving Accountability and Access to Remedy', A/HRC/ RES/32/10 (15 July 2016), Preamble.

26 Martin Krygier, 'Tempering Power', in Maurice Adams, Anne Meuwese and Ernst H Ballin (eds), Bridging Idealism and Realism in Constitutionalism and the Rule of Law (Cambridge: Cambridge University Press, 2019).

27 The World Bank good governance agenda often reduces the rule of law narratives to security of private property rights. World Bank, World Development Report 2017: Governance and the Law (Washington, DC: World Bank, 2017).

28 Christopher May, 'Market Exchange and the Rule of Law: Confidence in Predictability' (2018) 10:2 Hague Journal on the Rule of Law 365, 385.

29 David S Landes, Wealth and Poverty of Nations: Why Some Are So Rich and Some So Poor (New York: WW Norton \& Company, 1998).

30 Linarelli, Salomon and Sornarajah, note 16.
} 
depoliticized and solely about securing space for the market to flourish. ${ }^{31}$ In this interpretation, we do not pay attention to the people who have become subjects of this economic version of the 'rule of law' or perhaps note that the entire concept of the rule of law has been misused. In its most violent misuse, the rule of law can be used as a tool for extractive 'plunder' 32 by stronger political actors against weaker ones. The problem with this economic functionalist approach is that the entire normative concept of the rule of law as a means of removing arbitrary power and threat from peoples' daily lives is co-opted and misused. In parallel, it is unclear how private actors operating in highly unequal marketized settings, are themselves taking on board and functionalizing rule of law commitments within their own operations. This vision of the rule of law is more about the preservation of investor confidence than the role of law as a core tool for legality, fairness, reciprocity and substantive equality. The state can have an enabling role in the rule of law's transformative misuse.

Against this background, another casualty of financial globalization has been the principle of accountability. The dominant view of accountability presents state responsibility as the quintessential expression of accountability. ${ }^{33}$ Accountability as one of the core pillars of the rule of law often falls apart in the numerous legal and governance gaps between private parties (corporations, financiers, etc.) and harmed communities, when individuals are unable to access formal justice mechanisms due to 'legal and practical barriers to remedies'. ${ }^{34}$ To a large degree, the entire business and human rights (BHR) movement is a radical response to this legal deficit demanding to 'cast the net wider' to include accountability for corporations and financial houses. ${ }^{35}$ The UN Working Group on Business and Human Rights has pointed out, in this context, that 'the concept of effective remedies is closely connected to the idea of corporate accountability'. ${ }^{36}$ Globalization has, therefore, highlighted the inability of hard law to respond to the entire array of changing dynamics in which private actors and norms have become primary agents within their own transnational networks or clubs, of rule-making and standard setting. Examples include the numerous social and environmental performance standards and the provision of dispute resolution services as demonstrated through NCPs and the independent accountability mechanisms of development banks, all of which have real impacts on individuals and groups living in pluralized socio-legal contexts. ${ }^{37}$ Here the rule of law becomes inextricably wrapped up in how power works as any potential accountability and remedy will be intimately tied to

\footnotetext{
31 Jennifer Lander, Transnational Law and State Formation: The Case of Extractive Development in Mongolia (Abingdon: Routledge, 2020) 227.

32 Ugo Mattei and Laura Nader, Plunder: When the Rule of Law is Illegal (Oxford: Wiley -Blackwell Publishing, 2008).

33 Jutta Brunnée, 'International Legal Accountability through the Lens of the Law of State Responsibility' (2005) 36:1 Netherlands Yearbook of International Law 21.

34 Human Rights Council, note 25.

35 Margot E Salomon, Arne Tostensen and Wouter Vandenhole (eds), Casting the Net Wider: Human Rights, Development and New Duty-bearers (Antwerp: Intersentia, 2007).

36 UN Working Group on the issue of human rights and transnational corporations and other business enterprises, 'Report of the Working Group on the issue of human rights and transnational corporations and other business enterprises', A/72/162 (18 July 2017), para 80.

37 See, for example, Bhatt, note 17; Stéphanie De Moerloose, World Bank Environmental and Social Conditionality as a Vector of Sustainable Development (Zurich: Schultess, 2020); Türkelli, note 22.
} 
power, priority and economic trade-offs. ${ }^{38}$ Placed within this dominant and limited narrative of the rule of law, the OECD Guidelines and the NCP mechanism may also be viewed as a political and economic project for the transformation of governance, rather than a legal one. Yet, it has become common, certainly amongst those that are part of NCPs to present the mechanisms as legal, perhaps for legitimacy reasons. However, in terms of legal legitimacy, it is difficult to make the case that the OECD Guidelines obtain authority and legitimacy from any formal legal status, even though they may enjoy political, economic and social legitimacy.

Interestingly, NCP values strongly echo the rule of law perhaps clothing NCPs with legal authority and legitimacy. Their decisions must be visible, accessible, transparent, accountable, impartial, predictable and equitable and in conformity with the OECD norms. ${ }^{39}$ Even the most minimalistic interpretations of the rule of law agree that it should include a means to resolve disputes that is governed by independent judges ${ }^{40}$ or in the case of non-judicial avenues, impartial arbiters. There seems to be a high degree of consensus globally as to the basic elements of procedural fairness employed by NCPs and other state-based non-judicial remedy mechanisms. Nonetheless, issues such as lack of independence or lack of resources have been reported as detrimental to the enforcement of such elements of procedural fairness. ${ }^{41}$ While the impartiality of NCPs is an explicit goal in the OECD Guidelines, their independence is not guaranteed and often not the norm. The peer reviews of NCPs have revealed that not all NCPs are perceived to be impartial by stakeholders. ${ }^{42}$ On the other hand, impartiality is highly dependent on the structure, and many NCPs especially are housed in departments charged with investment promotion.

Transparency is interesting as it echoes the more formal and procedural values of global administrative law, which are primarily concerned with procedure as a way of indirectly policing power. ${ }^{43}$ It is therefore not surprising that many lawyers interpret the work of NCPs in specific cases as proxy for judicial review, even more so because the NCP procedure is used as a fall-back option if access to a regular court is unattainable in the host state or through the home state. For instance, an ex-Bralima worker participating in the 2019 workshop noted that the ecosystem of NCPs provided a safer, more flexible,

\footnotetext{
38 Giedre Jokubauskaite, 'Tied Affectedness? Grassroots Resistance and the World Bank' (2018) 3:5-6 Third World Thematics: A Third World Quarterly Journal 703.

39 The 2011 revisions to the OECD Guidelines brought values of accountability and impartiality into the NCP mechanisms. For reflections on these values in the context of the 2019 workshop, see Sanne Taekema, 'How Effective are the OECD National Contact Points? Lessons from the Bralima Case', www.eur.nl/en/esl/research/areas/ projects/approaches-rules-law-and-human-rights/events/reflections (accessed 19 June 2020).

40 McCorquodale, note 24, 282.

41 UN Office of the High Commissioner of Human Rights (OHCHR), 'State-based non-judicial mechanisms for accountability and remedy for business-related human rights abuses: supporting actors or lead players? Discussion paper prepared for the 6th UN Annual Forum on Business and Human Rights, Geneva' (27-29 November 2017) 15-16, https://www.ohchr.org/Documents/Issues/Business/DomesticLawRemedies/ARPII_\%20DiscussionpaperonPhase2for UNForum_FINAL (accessed 23 October 2020).

42 Impartiality was noted in the peer reviews of Austria (2019), Belgium (2016), Canada (2019), France (2018), Japan (2012), Norway (2014) and the United Kingdom (2019). On the other hand, the NCPs of Argentina (2019), Chile (2018), Denmark (2015), Germany (2018) and Italy (2017) were largely perceived as impartial in their practice. OECD, 'National Contact Point Peer Reviews', https://mneguidelines.oecd.org/ncppeerreviews.htm (accessed 22 October 2020).

43 Benedict Kingsbury, Nico Krisch and Richard B Stewart, 'The Emergence of Global Administrative Law' (2005) 68:15 Law and Contemporary Problems 15.
} 
accessible and cheaper forum through which to give the ex-Bralima workers a voice. This is especially true in the case in a fragile and conflict-affected setting such as the Democratic Republic of the Congo (DRC), where local justice mechanisms are seen by rights-holders to be easily compromised and eroded by politics and economics. In the Bralima case, the Heineken subsidiary Bralima had developed good relationships with the rebel armed group. ${ }^{44}$ In that case a judge and human rights worker that were sympathetic to the workers were shot by rebels: circumstances that would make workers think twice about using local systems and more generally, reflect the impact that global business has on shaping power and accountability locally.

In this context, the reliance on NCPs as remedy mechanisms is an indication of an ongoing transformation in the accountability governance regime that problematizes the transnational positioning of the two states involved in NCP activities: the home and host state. Under public international law, these two states are considered entirely separate legal subjects and while the host state has direct international legal responsibility for violations on its territory, it is the home state or jurisdictional 'seat' of a company that is, through the NCP mechanism, called to action. The relevant NCP, often sitting in a government department responsible for trade or industry, then acts as a sort of outsourced problem-solving interlocutor for the home state. Core state-centric rule of law concerns are taken up for the state within the machinery of an NCP and its good offices. Through these shifts in governance, states and MNEs may have constitution-like impacts through NCPs. Backer observes that as enterprises 'continue to grow... rule of law principles at the center of state-based law legitimacy will likely have to find expression in enterprise governance regimes as well, including those of the OECD Guidelines'. 45

The success or failure of accountability sought through NCPs is shaped by an NCP's own networks, funding and priorities, including for instance the individual quality of a specific NCP, budgetary allowances, flexibility of procedure and who is at the mediation table. ${ }^{46}$ This means that highly fragmented, unpredictable and opaque institutional factors determine whether or not cases will be successful. Thus, the effective use of the good offices may come to depend on unpredictable factors that are directly or indirectly tied to economic considerations. As a result, NCPs may be signalling an example of misuse in the application of the rule of law ideas that serve to advance a highly specific form of economically liberal rights. Yet, it must be remembered: to be democratic, new forms of accountability governance regimes should link to 'legitimacy, and transparency [as] key

\footnotetext{
44 Olivier van Beemen, 'En RDC, une poignée d'ouvriers fait plier le géant Heineken', Le Monde (18 August 2017), https://www.lemonde.fr/afrique/article/2017/08/18/en-rdc-une-poignee-d-ouvriers-fait-plier-le-geant-heineken_5173706_ 3212.html (accessed 23 October 2020).

45 Larry Catà Backer, 'The arc of triumph and transformation of the OECD Guidelines: Quo Vadis Triumph? Into an era of transformation! Triumphi quo vadis? Temporibus transmutatio parere' in OECD, OECD Guidelines for Multinational Enterprises: A Glass Half Full: A Liber Amicorum for Dr Roel Nieuwenkamp, Chair of the OECD Working Party on Responsible Business Conduct 2013-2018 (Paris: OECD, 2018) 43, 49.

46 UN OHCHR, 'Access to remedy for business-related human rights abuses: a scoping paper on State-based nonjudicial mechanisms relevant for the respect by business enterprises for human rights: current issues, practices and challenges' (17 February 2017) 21, https://media.business-humanrights.org/media/documents/files/images/ARPII_ FINAL_Scoping_Paper.pdf (accessed 23 October 2020).
} 
components' wherein 'a dedicated focus on power is required to illuminate how different forms of unequal power are generated and sustained in institutions for ... governance' ${ }^{47}$

In certain cases, access to NCP processes may end up entangled in power struggles across different international legal fora. A recent poignant example demonstrates how different mechanisms within IEL interact to the detriment of affected populations and the environment. In December 2019, roughly one month after a number of civil society organizations filed a claim against the United Kingdom (UK)-based company, Ascent Resources plc, at the Slovenian NCP (with the UK NCP in support) alleging hazards to the environment and health, lack of due diligence and adequate stakeholder engagement, ${ }^{48}$ Ascent Resources was preparing to sue Slovenia. ${ }^{49}$ The company sought to 'appeal against the decision of the Slovenian Environment Ministry to force the joint venture partners to carry out an unnecessary environmental impact assessment [EIA] for well stimulation work at its Petišovci project' if the appeal did not end favourably for the company. ${ }^{50}$ Although the complaint was declared inadmissible and closed by the NCP in March 2020, the company sent a Notice of Intent on 23 July 2020 to submit its investment dispute with Slovenia to international arbitration, alleging that the Slovenian Environmental Agency decision to require an EIA had adversely affected the investments of the Investors' ${ }^{51}$ Hence, competing legal structures are easily used by powerful commercial actors as a tool to protect the property rights of MNEs, casting doubt on the effectiveness of the entire NCP architecture. It also signals something about the hierarchies of IEL regimes which privilege formal, expensive, time-consuming and difficult to access formal dispute processes that MNEs can use to crowd out one of the very few avenues for affected communities to directly access those who hold the power in the international economic order.

In this transformative context, we can obtain fresh perspectives on changing legal authority and norm and subject creation under market globalization, which subsequently adds to Krygier's view on the misuses of the rule of law. It must be remembered, nonetheless, that 'the [rule of law] displays a double-edged, contradictory nature: it can favor oppression but it can also produce empowerment of the oppressed that leads to counter-hegemony'. ${ }^{52}$ Precisely because NCPs are one of the very few avenues for affected communities to seek remedies against powerful corporate actors, NCPs can also have a continued role in working towards a vision of the rule of law that holds power to account and empowers rights-holders. Some conceptual thinking in this vein would, we

47 Sarah Burch et al, 'New Directions in Earth System Governance Research' (2019) 1 Earth System Governance 1, 9.

48 OECD Watch, 'Focus vs. Ascent Resources plc', https://complaints.oecdwatch.org/cases/Case_555 (accessed 22 June 2020).

49 Friends of the Earth Europe, 'An Axe to Climate Action: 10 Reasons for the EU and Governments Must Quit the Energy Charter Treaty’ (May 2020), https:/friendsoftheearth.eu/wp-content/uploads/2020/05/ECT-axe-to-climateaction.pdf (accessed 13 May 2021).

50 Ascent Resources plc, 'Corporate Update' (17 December 2019), https://www.londonstockexchange.com/newsarticle/AST/corporate-update/14351165 (accessed 13 May 2021) (emphasis added).

51 Enyo Law LLP, 'Notice of Intent: Treaty Claims against the Republic of Slovenia by Ascent Resources Plc and Ascent Slovenia Ltd' (23 July 2020), https:/www.italaw.com/sites/default/files/case-documents/italaw11654.pdf (accessed 23 October 2020).

52 Mattei and Nader, note 32, 18. 
believe, help to better understand the reasons for the successes and failures of these mechanisms and bolster the arguments for reforming the structures of NCP mechanisms.

\section{Defining Effective Remedy}

This article first seeks to subject NCPs to empirically grounded scrutiny on their ability to offer effective remedy. Remedy, of course, may have different functions as highlighted by the Office of the United Nations High Commissioner for Human Rights (OHCHR)'s 'Accountability and Remedy Project' that investigated effective remedy for businessrelated abuses. These functions may include:

- compensation for those affected;

- reconciliation of parties in dispute;

- restoration of a previous state of affairs or rectification of harm;

- detection of breaches of the law;

- enforcement and sanctioning of wrongdoers;

- prevention of future harm (including through deterrence and the promotion of social dialogue); and

- review of administrative (i.e., governmental) decisions. ${ }^{53}$

Deva has pointed out that 'available remedies should combine preventive, redressive and deterrent elements', with all these elements being essential to ensuring 'the overall effectiveness'. ${ }^{4}$ This means that reparations go beyond simple 'guarantees of nonrepetition', to also comprise 'restitution, compensation, rehabilitation, [and] satisfaction'. ${ }^{55}$ Furthermore, the UN Working Group on Business and Human Rights has requested that rights-holders have access to a 'bouquet of remedies' which include restitution, compensation, rehabilitation, satisfaction, guarantees of non-repetition and other preventive remedies. ${ }^{56}$ The OECD Watch also takes a broad view on remedy by including 'an acknowledgement by an NCP of a breach of the Guidelines (i.e. an acknowledgement that a harm has been done), and a company's commitment to change its policies or practices moving forward (as a form of promise of non-repetition)' and 'compensation or actual changed circumstance on the ground for victims' ${ }^{57}$ Research on

\footnotetext{
53 OHCHR, 'A scoping paper', note 46, 22 (emphasis in original).

54 Surya Deva, 'Statement by Mr. Surya Deva, Chairperson of the Working Group on the issue of human rights and transnational corporations and other business enterprises $3^{\text {rd }}$ Session of the open-ended intergovernmental working group on transnational corporations and other business enterprises with respect to human rights' (25 October 2017), https:// www.ohchr.org/EN/NewsEvents/Pages/DisplayNews.aspx?NewsID=22303\&LangID=E (accessed 23 October 2020). 55 Ibid.

56 UN Working Group, note 36, paras 38-55.

57 OECD Watch, 'The State of Remedy under the OECD Guidelines: Understanding NCP Cases Concluded in 2019', OECD Watch Briefing Paper (17 June 2020), 2, https://www.oecdwatch.org/2020/06/17/the-state-of-remedy-under-theoecd-guidelines-in-2019/ (accessed 23 October 2020).
} 
symbolic forms of remedy concludes that the use of restorative justice perspectives may lead to 'the recognition of responsibilities for infractions of human rights ... through dialogue based on trust, without going through the process of accusation that is usually used in the ordinary justice system, which does not necessarily contribute to reconciliation and non-repetition'. ${ }^{58}$ The idea of reparations through dialogue is an important one in the context of NCPs, nonetheless dialogue pre-supposes that businesses will engage with the claimants through NCP good offices. In the absence of such willingness, effective remedy is impossible.

In the BHR domain, Principle 31 of the UNGPs sets out effectiveness criteria for nonjudicial grievance mechanisms which require them to be legitimate, accessible, predictable, equitable, transparent, rights-compatible and a source of continuous learning. ${ }^{59}$ Many of these parameters strongly echo the rule of law issues routinely applied in domestic settings and are also addressed in the Procedural Guidelines for NCPs as highlighted above. Although the UNGPs may be rightly criticized for failing to recognize the extent of home state obligations to regulate business enterprises ${ }^{60}$ and for constraining the discussion on direct business duties under public international law, ${ }^{61}$ they do provide a comprehensive overview of procedural conditions around effective remedy for rights-holders aggrieved by business-related wrongdoings. The Commentary to Principle 31 UNGPs also highlights the importance of designing remedy mechanisms effectively, as poorly designed or implemented remedy mechanisms may have compounding effects on rights-holders by heightening their sense of disempowerment. ${ }^{62}$

Procedural effectiveness criteria are only one part of the puzzle. Implementation is at least equally important as underscored by the European Court of Human Rights (ECtHR) stating that remedy must be 'effective in practice as well as in law'. ${ }^{63}$ The UN Working Group also notes that effective remedy involves procedural and substantive elements. ${ }^{64}$ Scheltema notes that the criteria in Principle 31 of the UNGPs should include several other parameters for gauging 'effective remedial outcomes'. ${ }^{65}$ These include, for Scheltema, consistency with human rights law at the national and international level, perception of the outcome as effective by business and local communities, positive impact on business performance in respecting human rights, on the individuals' enjoyment of human rights or enforceability of outcomes in practice, and alignment

\footnotetext{
58 Regional Business and Responsible Entrepreneurship Center (CREER) and the Institute for Business Ethics (IWE), Between Solidarity and Obligation: Challenges for the Participation of Businesses in Symbolic Reparation (CREER and IWE, 2019), 35, https://www.alexandria.unisg.ch/258966/1/Between\%20solidarity\%20and\%20obligation\%20challenges $\% 20$ for $\% 20$ the $\% 20$ participation $\% 20$ of $\% 20$ businesses\%20in\%20symbolic\%20reparation-1.pdf (accessed 23 October 2020).

59 UN Human Rights Council, note 10.

60 Daria Davitti, 'Refining the Protect, Respect and Remedy Framework for Business and Human Rights and its Guiding Principles' (2016) 16:1 Human Rights Law Review 55.

61 Türkelli, note 22.

62 UNGPs, note 10, Commentary to Principle 31.

63 Kudta v Poland, App. No. 30210/96, European Court of Human Rights (ECtHR) (26 October 2000), para 152; ElMasri v 'the former Yugoslav Republic of Macedonia', App. No. 39630/09, ECtHR (13 December 2012), para 255.

64 UN Working Group, note 36, para 3.

65 Martijn Scheltema, 'Assessing the Effectiveness of Remedy Outcomes of Non-Judicial Grievance Mechanisms' (2013) 4 Dovenschmidt Quarterly 190.
} 
with outcomes of other judicial and non-judicial mechanisms. ${ }^{66}$ From a practical perspective, effectiveness of remedy processes and outcomes necessitates accessibility, oversight, follow-up, enforcement capabilities and alignment through coordination. In addition, rights-holders' perspectives about the effectiveness of remedy should be prioritized to guide all practical considerations around remedy.

\section{The Post-Colonial Brewery: A Case Note on Heineken in the DRC}

The Bralima-Heineken case has been used as a proverbial poster child for the potential of NCPs to provide effective remedy to rights-holders within a rule of law framework when business enterprises are involved in wrongdoings. ${ }^{67}$ The narrative of success buttresses the status of NCPs as effective remedy mechanisms in the BHR domain, particularly by invocation in the UNGPs and the subsequent work to put the UNGPs into action, including through the OHCHR's work on remedy and accountability. Notwithstanding the positive outcome of the case, the overall picture of NCPs as effective remedy mechanisms is more complex. In what follows, we outline the historical context of the Bralima case, track the instance at the Dutch NCP and its outcome, and deconstruct the case in a contextualized way by situating it among empirical evidence on the performance of NCPs as effective remedy mechanisms.

\section{A. Heineken at the Dutch NCP}

Bralima is a subsidiary of the MNE Heineken NV and has been operating in the DRC for more than 90 years. Africa's second largest country, the DRC, is notoriously rich in raw materials and minerals but said to be 'cursed' by deadly violence, insurgencies, poverty and profiteering. ${ }^{68}$ Starting with rubber extraction in the nineteenth century, European powers began to infiltrate African markets with the assistance of private companies and banks. Since then, Congo's civil wars fuelled by blood diamonds and so-called 'conflict minerals' used for electronic devices, have ravaged the country and make operating any sort of business a dubious proposition. In this context, brewers are a rare colonial era holdout: a strange part of the history of colonial extraction and domination. ${ }^{69}$ In 1923 , a group of European investors founded one of Africa's first breweries, naming it Brasserie de Léopoldville after Belgian Congo's colonial-era capital. Bralima started its operation in the DRC during the Belgian colonial period in Leopoldville (Kinshasa). In 1987,

\footnotetext{
66 Ibid.

67 Roel Nieuwenkamp, 'Beer, Conflict and Compensation: Heineken Congo Agreement', OECD Insights (15 September 2017), http://oecdinsights.org/2017/09/15/beer-conflict-and-compensation-heineken-congo-agreement (accessed 19 June 2020).

68 Nadira Lalji, 'The Resource Curse Revised: Conflict and Coltan in the Congo' (2007), https:// www.globalpolicy.org/the-dark-side-of-natural-resources-st/water-in-conflict/40150.html (accessed 19 June 2020).

69 The Economist, 'Doing Business in Dangerous Places: How Heineken Beer Survives in Congo', The Economist (21 April 2018), www.economist.com/business/2018/04/21/how-heineken-beer-survives-in-congo (accessed 19 June 2020).
} 
Heineken NV directly acquired approximately 95 per cent of Bralima's shares, making Bralima a close business partner and a legal subsidiary of Heineken NV. ${ }^{70}$

In 2015, the Dutch NCP received a complaint from Namegabe Bugabo, Matabaro Rubanza and Bayongwa Mirimba, as representatives of a group of approximately 168 former employees of Bralima. The complaint alleged that Bralima had abused the human rights of 168 workers in its Bukavu factory during 1999-2003 by unjustly dismissing them and by co-operating with the rebel armed group RCD-Goma, which negatively impacted the workers and their families. ${ }^{71}$ According to the complaint, Bralima took advantage of a period of political turmoil in the DRC to quickly dismiss a large number of employees without authorization from the competent DRC labour authority, seeking that authorization from the rebel armed group RCD-Goma instead. This was in contravention of Congolese law, international law and the 2000 version of the OECD Guidelines then in force. The employees dismissed en masse were replaced by temporary workers. The workers claimed that Heineken, as Bralima's parent company, had or should have had knowledge of the situation and should have used its influence to prevent the abuse of the workers' rights. In failing to do so, the workers held that Heineken was responsible and demanded that it compensate them and their families for the harm.

After deeming the complaint admissible, the Dutch NCP initiated a process of factfinding and mediation, with Heineken and the workers agreeing to participate in good faith. Starting with the publication of its initial assessment on 28 June 2016, the Dutch NCP took several intermediate steps, including dialogue roundtables held in neutral territory outside the DRC (the Dutch embassies in Uganda and France) and separate meetings between Heineken and the workers. The result was a final agreement to the satisfaction of all parties and a rare instance of a government using its NCP mechanism to successfully implement and follow through on its duties under the OECD Guidelines.

The Final Statement of the Dutch NCP noted that Heineken committed to enacting policy and guidelines 'on how to conduct business and operate in volatile and conflictaffected countries'. ${ }^{72}$ It committed to analysing the company's existing policies and procedures against the benchmarks set by the OECD Guidelines and UNGPs. ${ }^{73}$ Beyond these commitments, the final agreement between the applicants and Heineken remains confidential. ${ }^{74}$ The Dutch NCP noted that while the promise of confidentiality may create a positive pull for businesses to engage with the NCP process, it is regrettable that confidentiality also prevents the complete array of lessons learned to be available to

\footnotetext{
70 Yvonne Erkens, 'After Fourteen Years the OECD NCP of The Netherlands Serves Justice for 168 Workers who have been Wronged during Times of Civil War' (2018) 4 International Labor Rights Case Law 112.

71 Wilde-Ramsing, 'Historic agreement between Heineken and former Congolese workers seeking remedy in labour rights dispute', SOMO (18 August 2017), www.somo.nl/historic-agreement-heineken-former-congolese-workersseeking-remedy-labour-rights-dispute (accessed 19 June 2020).

72 Dutch Ministry of Foreign Affairs (MFA), National Contact Point OECD Guidelines for Multinational Enterprises, 'Final Statement - Former employees of Bralima vs. Bralima and Heineken' (18 August 2017) 5, https:// www.oecdguidelines.nl/latest/news/2017/08/18/final-statement-notification-former-employees-bralima-vs.-bralimaheineken (accessed 2 February 2021).

73 Ibid.

74 Ibid.
} 
other NCPs and stakeholders. Reports indicated that monetary compensation had been offered to the applicants which the then Chair of the OECD Working Party on Responsible Business Conduct noted, was a rare occurrence for a resolution through the NCP mechanism. ${ }^{75}$

\section{B. Deconstructing the Bralima Success Story and Situating it Among Empirical Evidence}

The expert workshop sought to dissect the presentation of the Bralima case as a success story for NCPs as effective remedy mechanisms by listening to inside stories from those directly involved: the Dutch NCP, the local non-governmental organizations (NGO), Afrewatch, and international NGOs/lawyers for the employees, Heineken and the OECD. Drawing on these insights and with input from lawyers and advocates working with other NCPs, the workshop opened up into a broader discussion on the effectiveness of NCPs in providing remedies.

During the workshop, three key themes arose for explaining the success of the Bralima case with the Dutch NCP: accessibility, political and commercial will, and the wide publicity of the case. On accessibility, the Dutch NCP gave much weight to its willingness to make itself fully accessible to the complainants throughout the process. This was achieved by translating all key documents and, atypical of NCP cases, agreement by the Dutch government to partly facilitate travel costs allowing the complainants to participate where they otherwise would not have been able. Accessibility was further supported through the readiness of the parties to listen to each other, with one interlocutor stating that 'this was the most important thing'. The fact that most NCPs, including the Dutch one, do not have formal statutes of limitations supported participation. ${ }^{76}$ Related to accessibility and discussed at length in the workshop was the rare political will and commitment of the Dutch government, the NCP and Heineken to facilitate and solve the complaint. The close working relationship between the Dutch NCP and the company was visible through the interactions between the participants who, as they openly stated, were fully amenable to the process with that amenability being a major reason for success.

Another contributing factor to the success of the case was said to be the independence and transparency of the Dutch NCP. In the Bralima case, the Dutch NCP conducted a more transparent procedure with the process for submitting a complaint laid out on the Ministry of Foreign Affairs website, which also provides public statements containing details of the cases received. As discussed in the workshop, these factors added pressure on Heineken to work with the NCP and the complainants. Consequently, the case mobilized Dutch and international media attention around the labour violations but also focused on broader legal and accounting measures Heineken had taken to minimize tax liabilities in Africa. The reverberation of extractive colonialism in these

\footnotetext{
75 Nieuwenkamp, note 67.

76 Not all NCPs are open to complaints on issues taking place several years prior. The Danish and Brazilian NCPs have five- and two-year limitation periods, respectively.
} 
modern measures were, for a Dutch company with its own colonial heritage, perhaps too uncomfortable and promoted responses from Heineken. ${ }^{77}$

The overall picture is both positive and negative. Clearly, in this specific case, the Dutch NCP was able to function in a highly effective way, resulting in a Heineken-Congo agreement the details of which are not public but do include the payment of compensation to the dismissed workers. However, a closer look at the reasons for that success illustrate an indeterminate range of conditions for the successful use of the Dutch NCP's good offices. That recipe of conditions includes a fortuitous combination of circumstances and people that facilitated success. As Taekema notes, ${ }^{78}$ resolution will depend on many unpredictable factors such as the determination of claimants to pursue a claim, the cooperation of the company and the genuine interest of the relevant NCP to support the process - thus making the outcome highly vulnerable to the actors involved.

Following on from this positive outcome, a fuller picture of the effectiveness of NCPs to deliver remedy is required in order to contextualize our findings from the Bralima case. Unfortunately, empirical studies on the topic of NCP effectiveness are few. However, as this section discusses, some studies exist for contextualizing our case findings. ${ }^{79}$ Some paint a happier picture of NCP success. An analysis of multiple NCP complaints concluded that this alternative dispute resolution system that directly addresses complaints from civil society is well suited to resolving international investment disputes due to their accessibility and limited cost. ${ }^{80}$ Perhaps unsurprisingly those involved in the implementation of the OECD Guidelines and function of the NCP are keen to report that there is 'more remedy than you might think!' 81 by drawing on the success of the Heineken, Statkraft, Kinross and Mylan cases. ${ }^{82}$ Between 2000 and 2020, NCPs handled a total of 500 complaints. ${ }^{83}$ Yet, statistics on effectiveness are troubling. For instance, of the 250 complaints handled by NCPs between 2000 and 2015, only 14 per cent were shown to have yielded beneficial results such as an acknowledgment of wrongdoing ( 8 per cent), an improvement of company policy or procedure ( 8 per cent) and direct improvements for claimants ( 1 per cent, three cases). ${ }^{84}$ Furthermore, 'between 2011 and July 2020, 27\% of the concluded cases reported an unwillingness to engage

\footnotetext{
77 Olivier van Beeman, Heineken in Africa: A Multinational Unleashed (London: Hurst, 2019). The publication prompted responses from Heineken over allegations made in the book. Stephen Williams, 'Cutting Through the Froth', African Business Magazine (15 March 2019), https://africanbusinessmagazine.com/sectors/retail/cuttingthrough-the-froth (accessed 19 June 2020).

78 Taekema, note 39.

79 Letnar Černic, note 5; Stéfanie Khoury and David Whyte, 'Sidelining Corporate Human Rights Violations: The Failure of the OECD's Regulatory Consensus' (2019) 18:4 Journal of Human Rights 363.

80 David Collins, 'Alternative Dispute Resolution for Stakeholders in International Investment Law' (2012) 15:2 Journal of International Economic Law 673.

81 Nieuwenkamp, 'Outcomes from the OECD National Contact Point Cases: More Remedy than you May Think!', (5 December 2017), www.permanentrepresentations.nl/latest/news/2017/12/5/blog —outcomes-from-oecd-nationalcontact-point-cases-more-remedy-than-you-may-think (accessed 19 June 2020).

82 Ibid.

83 OECD, 'Database of Specific Instances', https://mneguidelines.oecd.org/database/ (accessed 14 May 2021).

84 OECD Watch, Remedy Remains Rare: An analysis of 15 years of NCP cases and their contribution to improve acces to remedy for victims of corporate misconduct (Amsterdam: OECD Watch, 2015) 19, https://www.oecdwatch.org/wpcontent/uploads/sites/8/2015/06/Remedy-Remains-Rare.pdf (accessed 23 October 2020).
} 
from one of the parties.' ${ }^{85}$ Similarly, the OHCHR's Accountability and Remedy Project has found through a review of over 431 BHR related events, allegations and disputes that often state-based non-judicial mechanisms such as NCPs do not offer an accessible or realistic route to an effective remedy. ${ }^{86}$

Some notable studies have given detailed examination to various factors that have hindered the ability of NCPs to consistently deliver effective remedy. Khoury and Whyte pinpoint the lack of any clear mechanism for enforcement as a major weakness in NCP effectiveness. NCPs cannot oblige companies to participate in the process, although they can recommend the withdrawal of government benefits. ${ }^{87}$ Another study finds that the voluntary nature of the mechanism is a key characteristic for understanding the 'piecemeal and inconsistent' 88 implementation of the OECD Guidelines. This is because the overall informality and voluntariness of the system supports an ad hoc and decentralized approach to implementing the OECD Guidelines within domestic NCPs.

Other shortcomings include a shortage of political will within NCPs to intervene, lack of NCP oversight through an independent ombudsman over concerns of arbitrariness, lack of predictability in NCPs' cases, bias and negligence. ${ }^{89}$ Consequently 'Remedy Remains Rare' and 'Obstacle Course' are the inauspicious titles of two comprehensive NGO reports on the effectiveness of NCPs. ${ }^{90}$ Against this background, the Dutch NCP stands out. Unlike many other NCPs, the Dutch NCP is not located within the business and trade department of the government - a position which others have noted can politicize an NCP by creating conflicts of interest. Letnar Černic also pinpoints the more transparent procedures of the Dutch NCP for the handling of complaints (compared with the US or Japanese NCP) and other factors that contribute to its effectiveness, for example, financial support from the Dutch government. ${ }^{91}$

Accessibility is an important issue in that affected persons who seek to access remedies through NCPs do so because they do not have recourse to effective remedies locally. The claimants often live far away from NCPs hosted in the home states of the private companies against which they are bringing claims. This means that bringing a claim against a company at a home state NCP is costly, sometimes prohibitively expensive, typically requiring travel as well as translation services to support proceedings in a foreign language. ${ }^{92}$ In many cases, the costs have to be borne by international civil society actors willing to support litigation for strategic reasons.

\footnotetext{
85 OECD, 20 Years and the Road Ahead', note 4.

86 OHCHR, 'Discussion Paper', note 41.

87 Khoury and Whyte, note 79, 371.

88 Gefion Schuler, 'Effective Governance through Decentralised Soft Implementation: The OECD Guidelines for Multinational Enterprises' (2008) 9:11 German Law Review 1776; Bernadette Maheandiran, 'Calling for Clarity: How Uncertainty Undermines the Legitimacy of the Dispute Resolution System under the OECD Guidelines for Multinational Enterprises' (2015) 20 Harvard Negotiation Law Review 205.

89 Khoury and Whyte, note 79, 369 and 376.

90 'OECD Watch, Remedy Remains Rare, note 84; Amnesty International, 'Obstacle Course: How the UK's National Contact Point Handles Human Rights Complaints under the OECD Guidelines for Multinational Enterprises' (London: Amnesty International, 2016), https://www.amnesty.org.uk/files/uk_ncp_complaints_handling_full_report_lores_0.pdf (accessed 19 June 2020).

91 Letnar Černic, note 5, 94-95.

92 OECD Watch, Remedy Remains Rare, note 84.
} 
Additionally, the impact of public scrutiny and publicity cannot be under-estimated and has played a vital role in the successful outcome of other cases. A case in the DRC was brought before the UK NCP in relation to the activities of SOCO, a British oil and gas exploration company, in a part of the Virunga National Park, a world heritage site. As an impressive success, a settlement was reached whereby SOCO agreed to halt its operations and to resume drilling within the park only if UNESCO and the DRC government confirmed that doing so would not impede its world heritage status. Moreover, SOCO committed to not conducting any operation in any other world heritage site in the future and to aligning its due diligence assessments with international standards and industry best practices. It was the first time a company agreed to cease its operations after a procedure before an NCP. A closer look at the case shows that multiple external factors contributed to this success, including an award-winning documentary called Virunga, and a strong World Wildlife Fund campaign prompting shareholders to rethink their investment in SOCO. ${ }^{93}$ The leverage that publicity and public scrutiny has on bringing company managers to the mediation table should therefore not be under-estimated when evaluating the reasons for NCPs' effectiveness.

Studies also find that NCPs have wildly different views over their roles and powers - a position that contradicts the principle of functional equivalence in the OECD Guidelines. As Sanchez notes, the disparity among endorsing states about the roles and powers of their NCPs will mean that there is no equal, consistent or predictable treatment of cases within the global NCP system affecting all interested parties. ${ }^{94}$

\section{Actions for Improving Effectiveness}

The positive outcome of the Bralima instance suggests that in the absence of more formal avenues for remedy and justice, the NCP mechanism may still serve important functions in giving claimants a voice, a chance to bring grievances to the attention of businesses and the possibility of remedy. Given that a number of adhering states are on the trajectory towards adopting mandatory human rights due diligence requirements for business enterprises, ${ }^{95}$ NCPs may prove to be complementary avenues to strengthen the rule of law by promoting the implementation of such mandatory measures for all companies, regardless of size or sector.

Currently, the potential of NCPs to provide effective remedy, both in procedural and implementation terms as identified in section III, remains curtailed by various limitations. These include their inability to compel businesses to take part in

\footnotetext{
93 Global Witness, 'Church of England divests from UK oil company SOCO International after Virunga scandal', Global Witness (2015), www.globalwitness.org/ru/press-releases/church-england-divests-uk-oil-company-socointernational-after-virunga-scandal (accessed 19 June 2020).

94 Juan Carlos Ochoa Sanchez, 'The Roles and Powers of the OECD National Contact Points Regarding Complaints on an Alleged Breach of the OECD Guidelines for Multinational Enterprises by a Transnational Corporation' (2015) 84:1 Nordic Journal of International Law 103.

95 France adopted the duty of vigilance legislation in 2017. Legislative drafts are underway in several countries such as Germany, Norway and Luxembourg. E Gilligan, 'Mandatory Human Rights Due Diligence: An Issue Whose Time Has Come', https://corporate-responsibility.org/issue-whose-time-come/ (accessed 19 June 2020).
} 
problem-solving processes, mandates restricted to non-adversarial measures and the provision of light 'good offices', the structural and ethical issues stemming from being located in a single government department, inadequate resources in dealing with claims from affected persons, and lack of independent oversight mechanisms. The assessment of the European Union Agency for Fundamental Rights on access to effective remedy in the BHR domain has highlighted several deficiencies within the NCP mechanism. While considering that NCPs 'may function as a complementary non-judicial remedy', the Agency, for instance, notes the lack of effectiveness in inducing change in business behaviour, excessively high thresholds for admissibility and compromised transparency and independence. ${ }^{96}$ On improving the effectiveness of NCPs, the Annex of the 2016 Council of Europe Recommendations on human rights and business focuses on improving transparency, visibility, accountability and impartiality and suggests concrete measures such as leveraging sanctions to back up recommendations. ${ }^{97}$

In sum and drawing on the Bralima case study and literature, we find that the effectiveness of NCPs is highly dependent on the general context of the case, specific NCP procedures, and a fortunate conjunction of external factors. Yet, adopting an optimistic outlook all the while recognizing the challenges endemic to the marketbased system of globalized economic interactions, our findings suggest that some tailored steps or actions through which willing NCPs might improve their effectiveness in delivering remedies by focusing on parameters identified in section III on effective remedy: accessibility, oversight, follow-up, enforcement capabilities and alignment through coordination.

Overcoming NCPs' limitations would clearly strengthen their status as grievance mechanisms for business-related harms and go a long way towards ensuring that NCPs can substantively deliver on their problem-solving mandate. As the Procedural Guidance of the OECD Guidelines accord adhering states the flexibility to organize their NCPs as they see most effective or fit, ${ }^{98}$ there is nothing that prevents adhering states from allowing their NCPs to acquire more proverbial 'teeth'. In this respect, incremental progress may be made through the following policy recommendations that strengthen NCPs as complementary mechanisms for access to effective remedy in line with the conditions for effectiveness explored in section III.

The first two proposals centre on improving procedural effectiveness, while the remaining three proposals aim to address the effectiveness of implementation of NCPs' decisions. These measures will work towards increasing rightscompatibility and the effectiveness of remedy both procedurally and in terms of outcome.

\footnotetext{
96 European Union Agency for Fundamental Rights (FRA), Improving Access to Remedy in the Area of Business and Human Rights at the EU Level, FRA Opinion (1/2017) 59-60, https://fra.europa.eu/sites/default/files/fra_uploads/fra2017-opinion-01-2017-business-human-rights_en.pdf (accessed 19 June 2020).

97 Council of Europe, 'Recommendation CM/Rec(2016)3 of the Committee of Ministers to Member States on Human Rights and Business' (2 March 2016), para 53.

98 OECD, Procedural Guidance, note 6, para 1A.
} 


\section{Increased Accessibility through Resource Allocation}

Accessibility is an important determinant of whether the remedy available will be procedurally effective, as demonstrated by the Bralima case and echoed by Principle 31 of the UNGPs. Setting up an independently administered trust for each NCP to provide communities, particularly those abroad, with funds for facilitating a mediation will improve accessibility. Such a mechanism would move towards a substantive levelling of the power imbalance between companies and communities giving them a measure of equality within mediation. An 'International Fund for Victims' to provide legal and financial for victims is envisaged in the proposed draft binding instrument on business and human rights. ${ }^{99}$

\section{Independent Oversight to Improve Impartiality}

Ensuring the independence of NCPs has been identified both by civil society and by the peer reviews of various NCPs as a means through which NCP proceedings and decisions can be rendered more legitimate, transparent, accountable and reliable. Such an initiative is crucial from a rule of law and effective remedy perspective. In fact, the commentary on the Procedural Guidelines for NCPs provides the possibility to establish multistakeholder advisory or oversight bodies for NCPs. ${ }^{100}$ Ideally, these bodies should include independent experts that can assess the various issues tackled by the OECD Guidelines such as human rights, labour, environment, competition, anti-corruption and anti-bribery. This would also ensure that there is continuous learning from the NCP practice, providing insights into how improvements can be made to the process.

The importance of oversight is demonstrated by the follow-up to the Human Rights Law Centre (HRLC) and Rights and Accountability in Development (RAID) v G4S Australia Pty Ltd (G4S) instance submitted in 2014 to the Australian NCP, regarding practices at the Manus Island Regional Processing Centre in Papua New Guinea. ${ }^{101}$ After the Australian NCP dismissed the instance, the OECD Watch sought to involve the OECD Investment Committee as an oversight body in line with the Procedural Guidance. ${ }^{102}$ After examining the OECD Watch submission, the Investment Committee found that the Australian NCP had not acted transparently or predictably

\footnotetext{
99 OHCHR, 'Open-Ended Legally Binding Instrument to Regulate, in International Human Rights Law, the Activities of Transnational Corporations and Other Business Enterprises, Second Revised Draft 06.08.2020, art 15, https:// www.ohchr.org/Documents/HRBodies/HRCouncil/WGTransCorp/Session6/OEIGWG_Chair-Rapporteur_second_ revised_draft_LBI_on_TNCs_and_OBEs_with_respect_to_Human_Rights.pdf (accessed 13 May 2021). Intergovernmental trust funds are set up by states or private entities for specified purposes including provision of legal/financial assistance to developing countries. Ilias Bantekas, 'Trust Funds', in Rüdiger Wolfrum (ed), Max Planck Encyclopedia of Public International Law (Oxford: Oxford University Press, 2010), https://opil.ouplaw.com/ view/10.1093/law:epil/9780199231690/law-9780199231690-e1122 (accessed 13 May 2021).

100 OECD, Procedural Guidance, note 6, paras 11-13.

101 Human Rights Law Centre (HRLC) and Rights and Accountability in Development (RAID), 'Complaint Concerning G4S Australia Pty Ltd - Submitted to the Australian and United Kingdom National Contact Points for the OECD Guidelines for Multinational Enterprises' (September 2014), https://www.raid-uk.org/sites/default/files/oecdcomplaint-g4s-australia.pdf (accessed 14 May 2021).

102 OECD Directorate for Financial and Enterprise Affairs, Investment Committee, 'Response by the Investment Committee to the Substantiated Submission by OECD Watch regarding the Australian National Contact Point' (30 November 2018), paras 6-7.
} 
and that some of its actions demonstrated impartiality and inaccessibility. ${ }^{103}$ The Investment Committee's assessment and recommendations prompted the appointment of the first ever Australian independent examiner for alleged misconduct by Australian MNEs abroad. ${ }^{104}$ Here, it must be noted that there was, since 2012, a committee overseeing the work of the Australian NCP but it was chaired by the NCP itself and included representatives from different government agencies and departments, hence, not independent.

\section{Sanctions to Improve Effective Implementation of Remedies}

Currently, there are no standard operating procedures applicable across all NCPs that compel the respondent company to engage with the claimants in good faith, raising questions around the predictability of the entire scheme from the perspective of communities. Business enterprises that do not experience negative effects, such as reputational costs flowing from specific instances, might simply refuse to participate. This is compounded by the fact that many business-related wrongdoings brought before NCPs take place outside of the state that houses the particular NCP and that most states do not currently have domestic legislation in place to regulate the activities of their businesses abroad.

The POSCO case demonstrates how ineffective the NCP mechanism can be in cases where the respondent companies simply refuse to engage. ${ }^{105}$ The Bralima case, on the other hand, demonstrates how successful NCPs can be with a willing company. The accent on voluntarism and the soft law nature of the OECD Guidelines means that NCPs cannot incentivize or compel businesses to engage with claims brought against them. Nonetheless, the practice of the Canadian NCP in the instance against China Gold International Resources Corporation (CGIRC), a company registered and headquartered in Canada and listed on the Toronto Stock Exchange, may provide inspiration. The Canada Tibet Committee (CTC) filed an instance with the Canadian NCP in 2014, regarding the death of 83 miners in the Gyama Copper Polymetallic mine, belonging to Tibet Huatailong Mining Development Ltd, a fully owned subsidiary of CGIRC. ${ }^{106}$ When CGIRC refused to engage with the NCP, it issued a final statement noting that CGIRC was not operating in a manner consistent with the OECD

\footnotetext{
103 Ibid, para 53.

104 Human Rights Law Centre, 'Australia appoints first-ever independent examiner to investigate corporate human rights abuses overseas' (31 July 2019), https://www.hrlc.org.au/news/2019/7/31/australia-appoints-first-everindependent-examiner-to-investigate-corporate-human-rights-abuses-overseas (accessed 24 September 2020).

105 The state-owned Norwegian pension fund NBIM refused to engage with the Norwegian NCP, notwithstanding the fact that the NCP found NBIM to be in violation of the Guidelines. OECD Watch, 'Case Database: Issue: POSCO's Involvement in HR and Environmental Impact in India', https://complaints.oecdwatch.org/cases/Case_260/ @ @ casesearchview?type=Issue\&search=en_POSCO's\%20involvement\%20in\%20HR\%20and\%20environmental\% 20impact\%20in\%20India (accessed 23 October 2020).

106 Canada Tibet Committee, 'Request for Review Submitted to Canada's National Contact Point Pursuant to the OECD Guidelines for Multinational Enterprises, Specific Instance Regarding: The Operations of China Gold International Resources Corp. Ltd., at the Copper Polymetallic Mine at the Gyama Valley, Tibet Autonomous Region' (2014) 5, https://ohchr.org/Documents/Issues/FAssociation/NaturalResource/Canada_Tibet_Committee1_ E.pdf (accessed 23 October 2020).
} 
Guidelines. ${ }^{107}$ Furthermore, the NCP recommended exclusion of the company from government trade promotion services for its failure to engage with the NCP process in line with the Canadian Government's policy on responsible business conduct. The 2019 peer review of the Canadian NCP noted that whilst many stakeholders support the sanction regime, there is a lack of transparency and understanding of the mechanism and its potential benefits among civil society and NGOs with the peer review calling for more publicity with respect to its applicability. ${ }^{108}$

The Canadian example demonstrates that NCPs can have an important role to play in facilitating state imposition of concrete sanctions to compel MNEs' adherence to the OECD Guidelines. However, it remains to be seen whether state-imposed corporate sanctions based on the recommendations of an NCP will be enforced in practice, a matter which will inevitably turn on the political and economic power of the specific MNE vis-à-vis the state at the specific time. Of course, some NCPs might take the view that threatening sanctions prevents companies from coming to the table in the first place (a point that was also raised during the Bralima workshop). Yet, unwilling companies may need to be nudged with tangible consequences.

\section{Compulsory Follow-up to Foster Longer-Term Effectiveness}

A fourth proposal is the introduction of compulsory follow-up to concluded instances. ${ }^{109}$ Even when they are successful in providing good offices, instances often end in promises of continued dialogue, mediation agreement or recommendations by NCPs. As the OECD Watch notes, '[m] not left to the request of the parties. Follow-up activities should include, at minimum, a request that the parties submit periodic reports to update the NCP on their progress and corresponding publicly available monitoring reports by the NCP'. ${ }^{110}$ The BralimaHeineken case provides a good example in this regard: the Dutch NCP was actively involved in monitoring the post-mediation process, including the dialogue between the parties, the choice of the Congolese labour expert and remained involved in evaluating implementation. ${ }^{111}$ These proposed policy changes should be implemented across all NCPs and by all states adhering to the OECD Guidelines, including through strengthening the role of the peer review process.

\section{Effective Coordination Between NCPs and their Policies}

Dialogue and coordination between NCPs in different countries may incentivize the harmonization of NCP practices across home states. As illustrated in the POSCO case,

\footnotetext{
107 NCP of Canada, 'Final Statement on the Request for Review Regarding the Operations of China Gold International Resources Corp. Ltd., at the Copper Polymetallic Mine at the Gyama Valley, Tibet Autonomous Region (2015)', https:// complaints.oecdwatch.org/cases/Case_324 (accessed 23 October 2020).

108 OECD, 'National Contact Point Peer Reviews: Canada' (2019), https://mneguidelines.oecd.org/ ncppeerreviews.htm (accessed 19 May 2021).

109 This was included in the list of recommendations made in OECD Watch, Remedy Remains Rare, note 84, 49.

110 Ibid.

111 Dutch MFA, note 73, 6.
} 
claimants and their representatives may take the same issue to different NCPs with different results. This is because the attitude of the relevant company and the perspective of the specific NCP dealing with the instance may result in different outcomes. Such was also the case when claimants and their representatives brought cases against major cotton trading companies for trading in Uzbek cotton during a period when it was widely documented that forced adult and child labour were being employed on Uzbek cotton fields. Some NCPs offered good offices (Switzerland, France) and external conciliation and mediation (UK); the German NCP relied on written submissions and talks between the parties. ${ }^{12}$ While a number of trading companies acknowledged the issues linked to the use of forced labour and pledged not to source until the issues were resolved, the instance at the German NCP ended in the claimants pledging not to criticize the company publicly for its prior Uzbek trading policies. $^{113}$

A similar fragmented treatment was demonstrated by the POSCO case, where POSCO's investment in India's Orissa state allegedly resulted in damage to the environment and land expropriation but had differing results in the three NCPs at which the case was filed, South Korea, the Netherlands and Norway. Shrugging home state responsibility for the actions of their businesses, the South Korean NCP rejected the instance after an initial assessment, stating that it was up to an Indian court to determine the legality and legitimacy of activities linked to the project. ${ }^{114}$ The Dutch and Norwegian NCPs accepted the instances against minority shareholding pension funds and cooperated during their assessments. ${ }^{115}$ The Norwegian pension fund NBIM, a stateowned enterprise, refused to engage with the Norwegian NCP on the matter, resulting in no real remedy at the conclusion of the instance. ${ }^{16}$ The Dutch pension funds, on the other hand, committed to exercising their leverage to improve POSCO's business practices. The Dutch NCP's final statement called on the three NCPs to co-operate and engage in a review and assessment mission in India. ${ }^{117}$ Moreover, the Dutch NCP concluded that the OECD Guidelines apply to all types of business relationships based on operations, services or products, including minority shareholders, whether or not the alleged harms are directly linked to the financial sector entities that engage in those business relationships. ${ }^{118}$

In this respect, best practices for improving the OECD Guidelines' effectiveness may include defining clearer procedures for coordination between NCPs and dialogue on the

\footnotetext{
112 Türkelli, note 22, 146-152.

113 Ibid.

114 South Korea OECD Guidelines National Contact Point, 'Initial Assessment of Complaint on Violation of OECD Guidelines for Multinational Enterprises - Lok Shakti Abhiyan et al. v. POSCO India' (11 May 2014), https:// complaints.oecdwatch.org/cases/Case_260/1287/at_download/file (accessed 23 October 2020).

115 Dutch NCP, 'Final Statement ABP/APG - Lok Shakti Abhiyan, KTNC Watch, Fair Green and Global Alliance, Forum for Environment and Development' (18 November 2013), 5.

116 Norwegian NCP, 'Final Statement: Complaint from Lok Shakti Abhiyan, Korean Transnational Corporations Watch, Fair Green and Global Alliance and Forum for Environment and Development vs. POSCO (South Korea), ABP/APG (Netherlands) and NBIM (Norway) (27 May 2013).

117 Dutch NCP, note 115.

118 OECD Watch, 'POSCO's involvement in HR and environmental impact in India', note 105.
} 
consequences of non-participation and/or non-compliance with NCPs' procedures. ${ }^{119}$ Better coordination could avoid situations where different NCPs end up with different conclusions and again, the peer review process can play a role to facilitate coordination.

The above policy suggestions move towards more substantive measures that address the power imbalances within NCP settings between rights-holders, private actors and state entities. Notwithstanding the more systemic changes needed to rethink the legal principles and structures that enable private actors to exploit the conditions of market globalization as explored in section II, improving NCP processes through independent oversight, the possibility of sanctions, compulsory follow-up and effective coordination between NCPs and their policies will improve the possibilities of holding private actors accountable.

\section{Concluding Remarks}

This article has shown that under current circumstances, the ability of NCPs to offer effective remedy is severely limited, inconsistent and unpredictable. It has sought to make sense of the sporadic successes and failures of NCP specific instances to deliver resolution for affected communities by situating NCPs within the broader legal order and critical political economic approaches to the current legal order that are so far missing from the existing literature on NCPs. As shown, NCPs are suited to this contextualization as they are increasingly portrayed as suitable non-judicial state-based remedy mechanisms in the BHR domain.

The OECD Guidelines were, themselves, a response from developed countries to the NIEO transnational governance reform initiative of the 1970s which sought to rebalance the structure of the global economy through reforms such as regulating MNEs. One of the ways in which the OECD Guidelines sought to achieve this was by providing a dispute settlement mechanism to affected people within an international legal order that keeps those voices structurally locked out. Given the historical formation of NCPs on the heels of the NIEO, this historical context can explain many of the limiting operational conditions of NCPs explored in this article.

In this context, we have argued that NCPs signal interesting new sites to witness some important developments around the instrumentalization (and misuse) of the rule of law norms such as legal authority, and norm creation in economically politicized settings of international investment. Our key study of the Bralima case demonstrates that successful outcomes at NCPs are contingent on specific soft institutional and economic realities of a specific case and the individual functions of a domestic NCP, rather than any hard legality of the mechanism that is backed up by legal sanctions. To this extent, NCP practice reflects the historical legacy of the OECD Guidelines as one of the voluntary, ad hoc, outsourced, non-coercive and 'principled pragmatic' ${ }^{120}$ responses of legal systems to the

\footnotetext{
119 Christine Kaufmann, 'OECD MNE Guidelines Quo Vadis? Making Responsible Business Conduct Work for Better Lives' in OECD, note 45.

120 'Principled pragmatism' was coined by John G Ruggie to describe his approach for the BHR field. OHCHR 'Principled Pragmatism: The Way Forward for Business and Human Rights' (7 June 2010), www.ohchr.org/EN/ NewsEvents/Pages/PrincipledpragmatismBusinessHR.aspx (accessed 22 June 2020).
} 
market and MNE power. As argued, these systems do not adequately hold MNEs formally accountable to individuals and communities for harms done beyond their home state borders. As such, NCPs are a site par excellence of state legal outsourcing and delegation in which communities are pushed further away from access to formal legal structures in order to find remedy and justice in a forum that is largely controlled by NCP 'experts' and companies. Cases are then determined according to non-transparent institutional criteria such as publicity, cost, NCP eligibility and even, the 'mood' of the company and the management at the time. Conceptually, NCPs therefore create a space in which powerful interests can work against structural transformation by setting the conditions for success and failure of individual specific instances.

Whilst the current practice of NCPs looks dreary, we remain hopeful for the future potential of NCPs to address the complaints of people affected by MNE operations. NCPs have the potential to become more effective remedial mechanisms through the implementation of the policy recommendations presented in this article. This potential would be further complemented by substantive legal reform that prevents the systemic outsourcing of access to justice from the state into the obscure state/private hybrid arbitrage setting of NCPs without any independent checks and balances. At the same time, we must tackle the artificial public and private divide in the legal conceptualizations of the global economy and think about more structurally legalized mechanisms that take the power asymmetries and extra-legal relationships involved in the international investment and financial architecture as serious and legitimate sites of legal authority and subject-hood in international law. 